Portland State University

PDXScholar

\title{
The Ethical Challenges of Community-Based CS Training at Portland State
}

Joseph W. Christman

Portland State University

Follow this and additional works at: https://pdxscholar.library.pdx.edu/honorstheses

\section{Let us know how access to this document benefits you.}

\section{Recommended Citation}

Christman, Joseph W., "The Ethical Challenges of Community-Based CS Training at Portland State" (2019). University Honors Theses. Paper 701.

https://doi.org/10.15760/honors.718

This Thesis is brought to you for free and open access. It has been accepted for inclusion in University Honors Theses by an authorized administrator of PDXScholar. Please contact us if we can make this document more accessible: pdxscholar@pdx.edu. 
The Ethical Challenges of Community-Based CS Training at Portland State Joseph W. Christman

Portland State University 


\begin{abstract}
This literature review investigates Service Learning, the Capstone program at Portland State University, and the CS version of that Capstone program in particular in order to evaluate the ethical issues surrounding them. To achieve this, this paper is split into a few sections. There is an explanation of Service Learning, and a brief overview of its history. Following that is a summary of the history of the Capstone Program at Portland State including a description of the CS Capstone program at Portland State. After that the paper investigates some of the legal challenges surrounding the use of free labor. Next, the paper will take a look at the open source movement, the status of Open Source software as a public good, and the degree to which it mitigates the ethical challenges involving free labor. The paper comes to the conclusion that there's a need for advocates and practitioners of Service Learning and similar types of experimental learning to reflect on the ethics of these types of pedagogies, specifically on the obligations of the university and the other organizations involved towards the students. The paper also makes some suggestions as to how the CS Capstone at Portland State can be improved.
\end{abstract}

Keywords: Service Learning, Experimental Learning, CS, Internships, Labor 


\section{The Ethical Challenges of Community-Based CS Training at Portland State}

As the price of college has risen, universities have been pressured to focus less on abstract issues and more on practical skills (Maldonado, 2018; Ramaley, 1996). This has encouraged universities to adapt new types of experimental learning to inculcate students with the skills they'll need to be successful in the workplace. This literature review will focus around the moral issues surrounding Service Learning, a type of experimental learning that attempts to combine education with service to the community with a specific focus on Service Learning as implemented at Portland State University.

The idea of Service Learning was invented in the late 1960s, but only came to prominence in the late 1980s partially as a reaction to the perceived anti-social behavior of the “me-generation" (Kenny \& Gallagher, 2002). Due to the decentralized way in which Service Learning was developed, there is much definitional ambiguity surrounding it. This may have contributed to its adaptation by allowing different organizations to adapt it to its their own needs. However, this flexibility also allows for Service Learning to be used in ways that are less idealistic than it was originally conceptualized. For example, service learning can be used as a way for universities to both reduce costs by hiring less faculty, and develop relationships with outside firms.

Portland State was motivated to adopt Service Learning in the mid to late 90 s in response to a combination of reduced funding due to tax cuts, increased demand for accountability from the public, a high freshman dropout rate, and demands from policy makers to solve more social and economic problems (Kecskes, Spring, \& Lieberman, 2004). Initially, faculty handled the 
relationships with outside firms. However, over time these relationships were institutionalized so that the university could focus more on institution-level goals (Flynn, 2015),

The form of Capstone at Portland State that I have direct experience with is the Computer Science Capstone. This is a class that runs for two terms in which the students are split into groups to work on projects. These projects are brought in from outside firms and organizations referred to as sponsors. A student designated as the team lead gets to pick the project that the team will work on.

This type of community based learning is beneficial in that it provides students with experience working on large projects in a way that simulates real world experience. However, there are potential ethical pitfalls. Students are obligated to perform free labor for outside organizations, sometimes for for-profit companies, to pass the class. However, the software developed in these classes is Open Source, meaning the source code is made publicly available. If we accept that Open Source software is a public good, this may help to mitigate some of the moral shakiness surrounding the use of free labor.

The legal status of laborers in the United States is not clear. The laws distinguishing volunteers, interns, and employees from one another are not as explicit as one would hope. This is problematic, because different laws apply to different types of laborers. For example, employees must be paid a minimum wage, while interns and volunteers do not. This legal ambiguity is unfortunate for Service Learning and adds a degree of risk for all parties involved.

An issue with fast-moving fields such as experimental learning is that new methods such as Service Learning are invented and implemented first, and ethical reflection only comes later. There are many papers on on the technical, theoretical, and practical aspects of Service Learning, but almost none on the ethical issues that surround it. The few papers that do focus on the ethical 
aspects of service learning almost entirely focus on the ethical obligations of the students, and almost none focus on the ethical obligations of the university or the outside organizations involved in Service Learning.

\section{1 - Method}

To analyze the moral subtleties and clashes of values that surround Service Learning, and the Capstone program at Portland State in particular, I will use a literature review.

I will review the history of the Service Learning movement, and experimental education in general in order to evaluate its origins and goals. To achieve this, I will search for histories of the movement, seminal papers, and attempts to define the concept. I will specifically search for disagreements and sources of conflict within the literature on Service Learning.

I will look at how service learning came to Portland State in the form of the Capstone program both to compare it to the wider Service Learning movement, and to look at the particular factors that influenced its conception and implementation. In this process, I will use papers from the major figures involved among others, including a university president, and the previous associate vice president for strategic partnerships. I will then discuss my personal experience with the Capstone program to provide a degree of personal context to the analysis.

Following that, I will take a closer look at the labor relations between the student, the university, and the outside organizations that come together due to Service Learning. I will look at recent legal papers that analyze the distinction between contractors, employees, and volunteers. I will also reference papers that tackle the legal issues that surround Service Learning and experimental learning in particular.

For the next section, I will look at papers that discuss Service Learning as a possible replacement for traditional ethics classes. First, I will look at papers that analyze it from a 
theoretical perspective, then I will look for papers that try to empirically test the theoretical claims. The two types of papers should complement each other.

After that, in order to better analyze the computer science capstone at Portland State in particular, I will look at papers and blogs that discuss open source software and the value conflicts around it. I'll also look for papers that particularly discuss the intersection between Service Learning and engineering. After that, I will summarize my conclusion

The majority of the articles I will use will be from peer-reviewed journals. However, due to the fast-moving and informal nature of some of the content I wish to cover, especially the content involving open source software, more informal blogs and websites will be cited from time to time.

\section{2 - Background}

\section{1 - What is Service Learning?}

There doesn't seem to be any single meaning to "service learning," though there have been many attempts to create a definition. The National and Community Service Act of 1990 which partially inspired the Capstone program at Portland State University never explicitly defines it, but by taking context hints we can guess it's something like community service with an explicit learning portion(Kennedy, 1990; White, 1994). One of the more interesting attempts came from Linda Mooney and Bob Edwards. They put different "community based learning initiatives" (CBLs) into a hierarchy where each member of the hierarchy includes all the items below it. By this hierarchy, service learning contains all of the elements of out-of-class activities, volunteering, and internships plus structured reflection. I see no evidence this definition has been widely adapted, but it is one of the few that effectively distinguishes it from similar concepts (Mooney \& Edwards, 2001) We'll find the definitional ambiguity of Service Learning will have 
an influence on its implementation. For this paper, I will use the broadest possible definition that covers as much that has been called Service Learning as possible.

\section{2 - History}

The earliest generally cited influence is Alexis De Toqueville, specifically his advocacy of civic participation in the context of a democracy. He argued that for an individualistic country to successfully implement a democracy, civic participation of the citizens is necessary, and thus the population would have to be educated to participate (Kenny \& Gallagher, 2002).

The most often cited influence seems to be John Dewey. He was a progressive educational reformer who was active in the late $19^{\text {th }}$ and early $20^{\text {th }}$ century. He felt that universities were built on false dichotomies formed in the medieval Christian era, such as the dichotomies between doing and knowing, and emotions and intellect. He felt that eliminating these dichotomies was an important part of the process of universities progressing into more democratic institutions. To eliminate these dichotomies, he advocated things like project-based and experimental learning. His work had a large influence on early Service Learning practitioners such as Rob Shumer and Dwight Giles (Kezar \& Rhoads, 2001; Stanton, Giles, \& Cruz Nadinne, 1999).

According to Kenny \& Gallagher the more formal beginning of the Service Learning movement was in the 1960s. Cultural changes influenced by the anti-Vietnam War movement and the Civil Rights movement placed pressure on universities to be more culturally responsive. This led to an era of educational experimentation (2002). The earliest documented use of the term Service Learning is from 1967. The term was used in reference to an internship program sponsored by the Southern Regional Education Board. This program allowed college students to gain academic credit or earn money for work on community projects. 
Service Learning's earliest period of mild popularity lasted from about the late 60 s to the early 70s. However, this momentum was short-lived. The programs were criticized for not being well integrated into the educational experience, and having a paternalistic streak towards community partners (2002). The period from the late 70s through the late 80 s is thus regarded as the "dark age" of the Service Learning movement. Not much progress was made, and the movement stagnated.

In the late 80 s, the idea of Service Learning began to gain popularity again, at least partially in response to the perceived rise of a "me generation," a self-centered, materialistic generation that cared more about their own financial gain than civic participation. Service Learning was viewed by some such as the founders of Campus Connect as a method to "correct" these tendencies (2002).

Campus Connect was an organization formed by a group of university presidents to promote civic participation. This organization put a lot of effort into promoting Service Learning, and is still heavily involved in Service Learning as of this writing (2002).

\section{3 - Why do universities do it?}

There are both more alturistic motivations, and more selfish motivations for universities to adapt service-learning programs. The more alturistic motivations include allowing students to apply their learned skills to "real" problems, using the students and resources of the university to serve the community, giving students experience working in teams, and nudging students to "become more involved in the community (White, 1994)." The addition of service learning to an academic program can also reduce students' feeling of alienation on campus (Kecskes et al., 2004). 
There are also more selfish motivations for universities to adopt these programs. One possibility outlined by Christensen, Rudnus \& Prodanoff is to provide students with project or design related learning with less faculty involvement than traditional academic projects such as theses and faculty-supervised student-lead projects. Less faculty involvement means lower costs, and less work for existing faculty. Reduced faculty involvement may also help to allow a university to hire less faculty. Design projects are required by some accreditation programs such as ABET, so having a lower cost method to fulfill that requirement can be beneficial (Christensen, Rundus, \& Prodanoff, 2003). Another motivation is for universities to ingratiate themselves to the local community in order to discourage cuts in funding from the local government, and increase investment in the university from outside firms (Ramaley, 1996).

A factor that doesn't fall into either category is outside pressure to focus less on the abstract questions traditionally associated with academia and more on "real issues (Ramaley, 1996)." Such pressure can be motivated by a desire to see the resources of the University used to affect real world change. The pressure could also be motivated by simple financial motivations as the cost of a university education rises.

\section{3 - Conflict Over Values}

The fast growth of the service learning movement has lead to disagreements over what exactly the goals and values of the Service Learning movement should be. Westheimer \& Khane said that "more attention has been focused on moving forward than on asking where we are headed. Due to the coalitions required to further the growth of the Service Learning movement, the movement has had to accommodate multiple agendas" (1994). These value conflicts include questions about the role of the university, charity vs change, and service vs internships. 


\subsection{1 - Charity vs Change.}

Westheimer \& Kahne categorized one of the points of contention as charity vs change. Charity is an experience that adds to the educational experience; change is something that transforms the educational experience. Involvement in charity programs is meant to promote some degree of alturism, while involvement in "change programs" are meant to affect the worldview of the participants in some meaningful way. For example, a charity based program might mandate that students volunteer for 100 hours at a facility of their choosing. A changebased program might involve students meeting homeless people and working to develop new ways to change their conditions in a systematic matter, and not just in a "gifting" matter.

To summarize, some believe that Service Learning can just be an experience that's tacked on to the student's education, while other's believe that Service Learning should change the student in some meaningful way. The latter worldview tends towards a more political view of Service Learning, while the former tends towards a more practical view. The practical view seems to have become more prevalent (Westheimer \& Kahne, 1994).

\subsection{2 - Role of the University.}

There is a general agreement that universities should emphasize teaching, research, and service. Unfortunately, different universities have different ideas of what these concepts mean. For example, service can mean producing students of strong character to serve the community, contributing original research to the public sphere, producing students with special sets of skills to serve the community, or some combination of all these (Pollack, 1999). Depending on the university's conception of service, the university's idea of Service Learning may differ, as well as its position on whether service learning should be its own category of classwork. If the 
university's existence is already a service to the community, why create a specific program for service?

There's also the question of what sort of relationship the university should have with the larger society. Should the university seek to add to the current social structure or transform it? If the university should add to society, then that would imply that the charity approach to Service Learning is sufficient. But, if the university should transform society, that implies that universities should aim to use Service Learning as a force of change.

\subsection{3 - Internship vs Service.}

The ill-definition of Service Learning has lead to the term being used to cover many different types of experimental education. Some of these programs focus solely on projects that resemble traditional community service work. Some even define Service Learning as explicitly excluding work at for-profit firms (Prentice \& Garcia, 2000). Other programs, especially in engineering, have involved for-profit corporations (Christensen et al., 2003; Faust, Greenberg, \& Pejcinovic, 2012).

An organization that certifies engineering colleges, ABET, requires "a major project that requires integration and application of knowledge and skills acquired in earlier course work (“Criteria for Accrediting Computing Programs, 2019 - 2020 | ABET," n.d.)." Service Learning doesn't have to be used to fulfill this requirement, but it is often used because it's cheaper and involves less faculty involvement than much of the alternatives (Christensen et al., 2003). These Service Learning projects often involve projects in collaboration with for-profit companies in contrast to the more idealistic idea of Service Learning. Some of them even resemble internships.

The increasing scope of Service Learning may be connected to its increasing institutionalization. Institutionalization requires the cooperation of multiple parties, some of 
whom will have other goals and motives than those traditionally associated with Service

Learning. Successful institutionalization will require some degree of compromise (Westheimer \& Kahne, 1994). The question is when does the compromise reach the point where Service

Learning begins to serve different goals and values than originally intended, and does that change matter?

\section{4 - Service Learning and the Capstone Program at Portland State}

In the early 1990s, the University began to lose funding due to a combination of tax cuts and decisions from local government. Other pressures on the University included increasing demand for accountability from the public, a high freshman dropout rate, and demands from policy makers to solve more social and economic problems (Kecskes et al., 2004). In 1991, the university began to make reforms at the administration level. Later, the university started an internal grant program to encourage faculty to adapt innovative teaching methods. In 1994, the provost appointed a committee to recommend a university-wide program of reform. The committee issued their report in 1996 recommending the capstone service learning program (Ramaley, 1996). The goals were that students would be able to apply the abilities they learned to real issues and problems, work in a team context, and become more actively involved in the community (White, 1994). There was some resistance from faculty, but the rollout was generally perceived as successful (Ramaley, 1996).

The program makes it a graduation requirement for senior undergraduates to take a twoterm Capstone class that involves some sort of service learning. Some departments choose to offer specialized versions of the capstone that share the same "design and intent (White, 1994)." For example, the CS capstone puts students into teams, and the teams get to select from a group 
of "sponsors" to complete projects from. These sponsors can be individuals, non-profits, or forprofit companies.

Initially, relationships with outside firms and organizations were handled at the facultylevel. In 2008, Wim Wievel became president of the university with the objective to formalize and institutionalize these relationships. To fulfill that objective he formed the Office of Strategic Partnerships (OSP). In 2013, they worked with the Office of Academic Innovation (OAI) towards a more formalized system. In 2014, PSU launched the PSU Community Partnership Council to further push community partnerships. At this point, the university began to place emphasis on "strategic partnerships," partnerships with outside firms that required coordination to make sure "institution-level" goals are met. Effectively, relationships with outside firms moved from faculty-level to institution-level (Flynn, 2015).

It's worth asking if professors having to worry about institution-level relationships with outside firms could affect the way community based learning classes are taught. For example, if a firm engages in ethically questionable behavior in relation to the students, the professor might be put in a position where he/she has to balance the well-being of his/her students against the university's institutional relationship with the firm. This could place a new type of pressure on the professor that didn't exist when the relationships just existed at the faculty level.

\section{5 - CS Capstone}

CS students get a different experience from the general Capstone program. Students are split into teams of 6-9 students lead by a Team Lead, a student selected by the instructor. The teams are given a choice of software projects to chose from presented by sponsors. These sponsors can be non-profit companies, for-profit companies, and individuals. The coordinators of the program "pretty much insist" that the software developed through the program be released 
under an open source license("PSU CS Capstone Sponsor Information,” 2017) (licensing is discussed in further detail in section 4). Each student is expected to work about 12 hours a week over 15 weeks.

The working group's 1994 report stated “our recommendation is that students in those majors and programs that currently have or subsequently develop senior level experiences similar in intent and design to the capstone not also be required to complete the capstone requirement (White, 1994)." That brings up the question: is the CS capstone similar in intent and design to the general capstone program?

The report presented three goals for students in the Capstone Program:

1. Students should apply the abilities they've learned to real issues and problems.

2. Students should work in a team context.

3. Students should become more actively involved in the community(White, 1994).

The CS capstone seems to cover the first two reasonably. The third part is a little more questionable. It depends on what we mean by "involvement in the community." If we take the phrase literally, then the CS capstone certainly meets the requirement. However, it seems to me that the phrase suggests something slightly more idealistic than mere passive involvement in the community. It seems to imply some sort of service, and I'm not sure every project that's been done in the Capstone Program would fall into that category.

\section{6 - My Experience}

I am an undergraduate senior Computer Science student at Portland State University. I have completed the capstone project.

I worked on a team that produced a lightweight FTL for use in embedded operating systems. The client was an individual who specializes in building lightweight operating systems 
for use in amateur rockets. All of the code was released under a GPLv2 license, an open-source license that requires anyone who modifies the code to release the modifications. Overall, I found the capstone to be a positive experience; however, the project did not meet all criteria of a more idealistic form of service learning.

On the one hand, I do feel that the project did a good job at meeting ABET requirements. It was a project-based experience with a learning component. It required independent work and research. The process of researching something obscure and implementing it independently (at a group level) is different from the general classroom experience. This process would likely be especially useful to people with no work experience. I did not feel exploited, and I felt like the work was going to a good place. In my case, It was not done for the benefit of a big corporation, as the project was mainly done for hobbyists.

However, as far as the service aspect goes, it was a little questionable, at least by traditional definitions of service. It wasn't connected to disadvantaged groups in any easily visible way. There wasn't any idealistic "saving the world" aspect either. It was mostly a project for hobbyists, which is ok, but it's hard to connect it to a traditional sense of service. The software was released open source, so theoretically, outside members of the community could use it. However, I don't know how many members of the outside community would desire to directly interact with such niche software. You could say that if it got picked up in a major product, it could indirectly affect a lot of the community, but you could say that about anything created in any job or internship.

From my experience viewing projects and interacting with other students, I get the impression that the Portland State CS capstone experience can be a highly varied experience. The experience students have is largely dependent on the team and the sponsor. Some sponsors are 
extremely hands on, and some aren't. Some sponsors are individuals, and some are large firms. It would be difficult to summarize one experience as if it applies to everyone.

During the Capstone, I reflected on my experiences in the broader context of the capstone program at Portland State. The mix of private firms, open source licensing, and intellectual property raises some questions about the implications of these types of projects both at the university and society level. I'll explore some of these questions in more depth in the next section.

\section{3 - Ethical Implications}

\section{1 - Do motivations matter?}

Firms tend to emphasize economic and technological priorities over social priorities (Bonaccorsi \& Rossi, 2006). This raises a question for universities designing service learning programs: should we take the motivations of outside partners into account before offering them free labor? Some authors, such as Egger, have argued that the motivations don't matter, it's free labor either way (Egger, 2008). Most other researchers, however, have attempted to distinguish service learning from other types of community based learning such as internships on the basis of an emphasis on service to the community (Sigmon, 1979).

Most historians of Service Learning, such as Kenny \& Gallaher's attribute Service Learning to idealistic origins. It came from educators who worked during the Civil Rights era and were at least partially influenced by John Dewey. It later rose in prominence in the late $80 \mathrm{~s}$ and early 90 s as a response to the perceived excesses of the me generation (Kenny \& Gallagher, 2002).

Some of the pioneers of the movement had grand visions of Service Learning being a force for societal change enhancing democracy and transforming the system (Kezar \& Rhoads, 
2001). However, it seems that much of today's Service learning adds to the system; rather than transforming the system. Much of it is more akin to an internship than the original grand vision shared by some of the pioneers.

Should the practitioners of Service Learning should be more selective about the firms they choose to work with in order to better meet Service Learning's original vision. Or, perhaps, the old vision was antiquated, and Service Learning just evolved away from it in order to serve other goals?

\section{2 -Labor status of students?}

Are students who participate in service learning programs employees, interns, contractors, or just students? And, then, who are the students contractually obliged to, and what obligations exist on both sides of that relationship?

\subsection{1 - The Legal Side.}

Based on Goldstein's analysis, the students are almost certainly in some way in a contractual relationship with the outside organization whether implicit or explicit. The main question after that is if the relationship is related to employment, an internship, volunteerism, or an independent contract (Goldstein, 1990)? If the relationship is employment, the students may be entitled to minimum wage under the law.

There is no easy legal answer to that question right now, because that part of the law is in a state of flux. Paul Budd provided a legal analysis of the current situation.

\subsubsection{1 - What are Interns?.}

The Fair Labor Standards Act (FLSA) was passed in 1938, establishing a national minimum wage for all employees. Some degree of exemptions exist for students, trainees, 
independent contractors, volunteers, and some white collar workers. Unpaid interns generally fall under the trainee exception. But, what is a trainee?

The first major legal case involving trainees to reach the Supreme Court was Walling v. Portland Terminal Co. A railroad that provided a week-long training course to potential employees. The court found that the trainees did not displace any of the railroad's regular employees, and did not expedite their work. In fact, they impeded the regular employees in some circumstances. The railroad won the case, and the participants were declared to be trainees, and were not owed a minimum wage.

Based on Walling v. Portland Terminal Co., the Department of Labor (DOL) put out an opinion letter in 2010 declaring that interns fall under the trainee exception, if they pass a six part (or, as of very recently seven-part) test. This is the test as of April, 2019. The relationship between the employer and the individual depends on:

1. The extent to which the intern and the employer clearly understand that there is no expectation of compensation. Any promise of compensation, express or implied, suggests that the intern is an employee-and vice versa.

2. The extent to which the internship provides training that would be similar to that which would be given in an educational environment, including the clinical and other hands-on training provided by educational institutions.

3. The extent to which the internship is tied to the intern's formal education program by integrated coursework or the receipt of academic credit.

4. The extent to which the internship accommodates the intern's academic commitments by corresponding to the academic calendar. 
5. The extent to which the internship's duration is limited to the period in which the internship provides the intern with beneficial learning.

6. The extent to which the intern's work complements, rather than displaces, the work of paid employees while providing significant educational benefits to the intern.

7. The extent to which the intern and the employer understand that the internship is conducted without entitlement to a paid job at the conclusion of the internship. Courts are not legally obligated to adhere to the DOL opinion letter, its power is only persuasive. However, some circuit courts have used the six/seven part test to different degrees. Some courts have interpreted it as all-or-nothing: If the employer fails to meet any part of the standard, the relationship is employment, and the employee is entitled to minimum wage. Other circuit courts have chosen to use the test but interpret it in the context of the totality of the circumstances. In other words, an employer might not meet one of the prongs of the test, but it may still be an internship.

There have been alternate legal standards that have been proposed:

1) FLSA Employee Definition: Some courts have decided to use the definition of employee from the FLSA, which can be summarized as an individual is an employee if the employer allows the individual to work in the interest of the employer. This standard is very broad relative to the other standards, and would probably declare most internships to be employment relationships.

2) Primary Beneficiary Test: This test looks at who is the primary beneficiary: the individual doing the work or the employer? If the employer receives the primary benefit from the relationship, then the individual is an employee. If the employee receives the 
primary benefit, then the individual is a trainee. This standard favors the employers much more than the other standards (Budd, 2015).

\subsubsection{2 - What are Volunteers?.}

Bodtke provides an analysis of the current legal system surrounding volunteers.

The dictionary definition of volunteer is a "person who voluntarily offers himself or herself for a service or undertaking." Susan Ellis and Katherine Noyes have proposed an alternative definition that covers groups like the peace corps that do receive some degree of compensation: "to choose to act in recognition of a need, with an attitude of social responsibility and without concern for monetary profit, going beyond one's basic obligations."

The FLSA has an explicit exception for volunteers, however, the FLSA only defines volunteers as people who work uncompensated for public agencies and soup kitchens. In practice, the DOL and courts have expanded this to also include charitable, religious, and nonprofit organizations. The FLSA prohibits for-profit businesses from accepting volunteer services unless the volunteer meets the standards for a trainee, in which case, we can speculate they're a trainee or an intern (Bodtke, 2014).

\subsubsection{3 - What are Independent Contractors?.}

The most common legal test used today to determine if an individual is an independent contractor is the common-law agency test. The common-law agency test has been used in the Supreme Court in Community for Creative Non-Violence v. Reid. The test is based on the following factors:

1. The extent of control which, by the agreement, the master may exercise over the details of the work;

2. Whether or not the one employed is engaged in adistinct occupation or business; 
3. The kind of occupation, with reference to whether, in the locality, the work is usually done under the direction of the employer or by a specialist without supervision;

4. The skill required in the particular occupation;

5. Whether the employer or the workman supplies the instrumentalities, tools, and the place of work for the person doing the work;

6. The length of time for which the person is employed;

7. The method of payment, whether by the time or by the job;

8. Whether or not the work is a part of the regular business of the employer;

9. whether or not the parties believe they are creating the relation of master and servant; 10. and Whether the principal is or is not in business.

There have been alternate tests used, but this is the one that the Supreme Court has used most recently (Pearce, 2018).

\subsubsection{4 -So, really, what are Service Learners, legally?.}

We have many terms to work with here, and they're all poorly defined to some degree. Service Learning is poorly defined and covers a lot of different types of work. On the other side, the line between contract workers, employees, volunteers, and interns is almost as poorly defined. There are a few speculations I can make, however. Service Learning done with public, non-profit, religious, and charitable organizations is probably legally volunteerism. Any service learning done with for-profit organizations, on the other hand, probably does not qualify as volunteerism. At best, it's an unpaid internship or an independent contract, and the employer will have to be very careful that the students meet the requirements for a trainee under the FLSA. If they act without care, they might find themselves in an employer-employee relationship with the students, and be legally obligated to pay minimum wage and any other requirements from the 
FLSA. I remain unsure about how to define relationship between an individual who commissions a Service Learning project and a student who works on the project is. It would seem prudent for such individuals to incorporate.

\subsection{2 - The Non-Legal Side.}

When students enter Service Learning programs voluntarily, it seems fair to call it volunteerism. However when universities such as Portland State University institutionalize these programs, they begin to feel like something else. It seems difficult to call something volunteerism if students must participate in them in order to graduate, and if they don't, they risk losing thousands of dollars, and not attaining their degrees.

In these situations of institutionalization, the term internship, in a non-legal sense, feels closest to the mark to me. It is a situation in which students work for free in hope of attaining knowledge, experience, and their degree. If correct, this type of Service Learning shares the ethical baggage that come with traditional unpaid internships.

\section{3 - Is service learning a reasonable replacement for a traditional ethics class?}

Some researchers have advocated service learning programs as a superior alternative to ethics classes, which are often lowly regarded (Kolenko, Porter, Wheatley, \& Colby, 1996).

The theoretical foundations for Service Learning as an alternative to a traditional ethics class are numerous. Through the course of service learning, students are introduced to moral dilemmas. They're often exposed to long-term, difficult, and intractable problems that they might not have been exposed to otherwise. They may gain awareness of wider societal problems, and through the process of coming into contact with the people who work with and suffer from these problems, humanize the problems (Godfrey, 2000). 
This theory of Service Learning seems to lean heavily on the idea of Service Learning being a force for change rather than being solely charity.

On the empirical side, the use of Service-Learning as an inculcator for moral development has seen mixed results. A doctoral thesis from Stanley Cram attempted to compare the moral development of students who went through a traditional ethics course and students who participated in a course based around Service Learning. He found no significant moral development in either group. He actually found marginally more growth in the group who took a traditional ethics class. Cram also found a slight and insignificant decrease in self esteem from both groups, with the Service Learning group having the bigger decline (Cram, 1998).

A metastudy focusing on the effect of service learning on moral development in general found a small, but significant effect size. The metastudy also found that Service Learning programs that involved reflection had a higher effect size than programs that did not. They also found that the children generally had larger effect sizes than adults (Conway, Amel, \& Gerwien, 2009).

While there is a theoretical case and a small empirical case to be made for Service Learning as a psuedo-ethics class, the empirical data does not seem to justify any sort of mass replacement of ethics classes with Service Learning courses.

\section{4 - Open Source/IP}

\section{1 - What is open source?}

The software that runs on computers consists of $1 \mathrm{~s}$ and $0 \mathrm{~s}$. This is because computers receive information in the form of electrical pulses that are generally said to be on or off. However, this format is not particularly intuitive to human beings. For that reason, we generally use invented programming languages that consist of symbols that are more intuitive to us to 
write software. They usually look like a combination of English and Algebra. However, the computer cannot read these symbols, so they have to be converted into $1 \mathrm{~s}$ and 0 s before the computer can run them. The pre-converted symbols are referred to as the "source code" while the converted symbols are called the "binary" which is what the computer actually reads.

For example, in figure 1, the source code for a traditional "Hello World" program is in the upper left corner, the binary in the top right corner, and the program is shown running at the bottom.

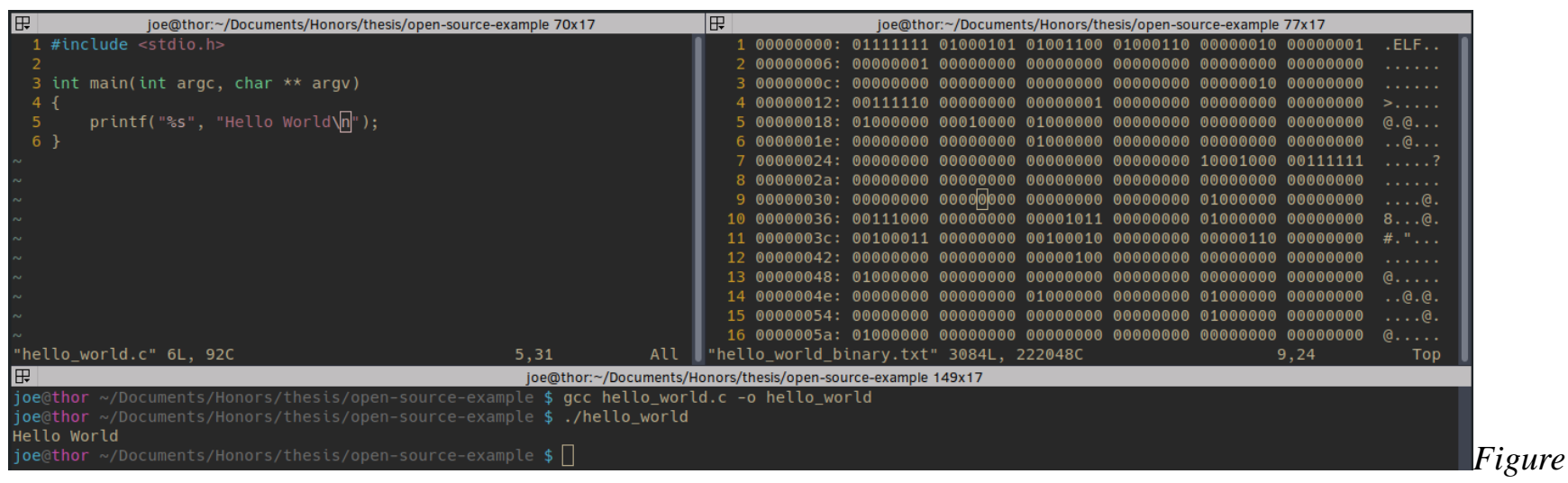

1: Source code on top-left, binary code on top-right, program running outputting "Hello World" on bottom.

The applicability of copyright laws to software is a touchy subject. Courts have come to the conclusion that software, and by extension the source code of software, is a literary product, and hence can be copyrighted (Lemley, 1995). In broad terms, open source software is software for which the source code is freely available, and anyone is allowed to modify it or distribute it as they wish.

Some organizations and authors have attempted to define open source in both broader and narrower terms. The main dispute has been between the more ideological "free software" side, and the more pragmatic "open source" side (Gacek \& Arief, 2004). The two approaches are not 
necessarily contradictory (Stallman, 2009), and the terms "Open Source" and "Free Software" are often used interchangeably. However, there remains much animosity between the two camps. Much as how we can view the split in the Service Learning movement as being between those who advocate a revolutionary pedagogy and those who advocate an additive pedagogy, we can view the the Free Software camp is revolutionary, and the Open Source camp as additive.

Stallman, a famous advocate of the more revolutionary free software side, wrote an article entitled "Why "open source" misses the point of free software" to contrast his views with the more pragmatic camp. Stallman views Free Software as an ethical gambit, not a technological one. He views "free software" as explicitly political; it's an act of social solidarity. He believes that proprietary software takes away fundamental rights from the user, such as the right to run, study, modify, and redistribute the software. He states if it was proven closed source technology was technologically superior in every way, he still wouldn't use it because it denies the users their fundamental rights (Stallman, 2009).

The Open Source side, by contrast, advocates Open Source software for pragmatic and technological reasons ("History of the OSI | Open Source Initiative"). The Open Source partisans don't talk about ethics, they talk about the technological strengths of Open Source. This is done at least partially to appeal to large corporations that wouldn't react well to the more political rhetoric associated with Stallman (Raymond, 2012). Therefore, the Open Source camp could be said to be more additive in contrast to the more revolutionary Free Software camp.

This revolutionary vs additive contrast can also be seen in the types of licenses that exist. The Free Software side has generally leaned towards more restrictive licenses. ("Various Licenses and Comments about Them - GNU Project - Free Software Foundation (FSF)"). Critics of these restrictive licenses have accused them of having a "viral" effect. For example, if any 
GPL code gets added to a project, the whole project becomes GPL (Phillips, 2008). The Open Source side, on the other hand, has tended to take a more neutral stance towards licenses.

Generally, more permissive licenses originate from an academic environment. They allow users to use the source code, and if they make changes, they are allowed, but not required, to open source the changes. The most prominent examples of permissive licenses in current use are MIT, BSD, and Apache. The more restrictive licenses, by contrast, mandate that anyone who makes changes to the source code has to open source the changes. Examples of these licenses include GPL and MPL (Lindman, Paajanen, \& Rossi, 2010).

Restrictive licenses, also sometimes called copyleft licenses generally center around a legal trick invented by Richard Stallman. These licenses use copyright to mandate that anyone who makes a modification to the application release the source code of the modifications ("Permissive and Copyleft Are Not Antonyms | Open Source Initiative," n.d.). The intention of these licenses are to keep firms from making changes to an Open Source application, then releasing the modified version of the open source application as proprietary software.

\section{2 - Implications of the use of Open Source Software in a Service Learning Course}

Open source software has been theorized as a public good (Bessen, 2006). A public good is a good that is indivisible, and non-excludable (Kollock, 2019). At least theoretically, open source software meets these requirements because it would be difficult to keep any part of a piece of Open Source software from anyone who wants it.

As far as the non-exclusivity of open source goes, it is worth asking if something actually has to be easily accessible to a large range of people, or just theoretically so. For example, if I write a piece of software, make the source code publicly available, but nobody sees it or uses it, 
is it a public good? Or, what if only a limited clique such as a firm uses it? Is this a public service, or does it become a de facto exclusive service? Is it enough just to create Open Source software, or does an effort have to be made to make it accessible to wide audiences in order for it to be a public good?

If we accept open source software is a public good, then is producing open source software an act of service to the community? Does the content of the software being written matters? Let's say that the FOSS project is a cruise missile guidance system. Is its creation and introduction to the public domain still a service?

There's evidence that this isn't a universal view. Some Service Learning teachers have used a new category of open source Software called Humanitarian Free and open source Software (HFOSS.) This is a category of open source software that specifically focuses on humanitarian goals such as disaster management, management of medical records, microfinance, and things of that nature (Ellis, Hislop, Jackson, \& Postner, 2015). The very existence of this category shows that at least some people don't see writing FOSS in itself as necessarily a public service.

As noted previously, open source licenses can widely be divided into two camps: restrictive and permissive. Portland State allows the sponsor and the students in cooperation to choose either type. It seems conceivable that firms could request students do work under a permissive license such as MIT or Apache, then they could make some small modifications and release the new codebase as a proprietary product. It seems this could get around some degree of the public good value of the open source code. 


\section{3 - Discussion}

\subsection{1 - Licensing Options in the Spirit of Service Learning.}

In an abstract sense, writing Open Source software could be seen as a service, or positive act, for the community. It provides knowledge to the community that can be built upon by others. This could be seen as similar to the traditional role of a university, releasing knowledge into the community.

On the other hand, can Open Source software be a de jure a public good, but de facto limited to a small community? It has been estimated that there are about 23 million software developers in the world out of a population of 7.5 billion, meaning less than $1 \%$ of the world population will be able to use any code developed ("Evans Data Corporation | Global Developer Population and Demographic Study 2018 Vol. 2"). Once you consider knowledge of a source control system and the niche nature of many of the projects, you're actually probably dealing with a much lower number of people who can actually use the code. Can a good that so few people can use directly really be said to be a public good?

Aaron Swartz made a similar point in his analysis of the userbase of Wikipedia. He found that the difficulty of the editing process excluded a lot of people. Even Richard Stallman had difficulties with the editing process (Swartz, 2006). It takes a lot of infrastructure to make something accessible to a large amount of people including educational resources, documentation, and the design of the software in the first place. The main mechanism through which Open Source software is distributed in the modern era is through version control systems, mainly git, which is notoriously difficult to learn even for programmers (Munroe, 2015).

On the other hand, could this be said about all academic knowledge? Willinsky argued that the modern Open Source movement is just an extension of what academia has done 
traditionally. Academia has cultivated knowledge, and generally shared it both publicly and privately without an expectation of payment. Open source software can be said to just be an extension of this tradition (Willinsky, 2005).

It seems if we were to follow that logic, however, universities would be public goods in themselves, and there'd be no need for a separate service class. It seems like the want for a service class implies a desire for something beyond the traditional role of a university.

At Portland State, the sponsors and the students get to decide on the license of the student's work (Massey, 2019). This is positive in that it could provide the students some degree of freedom as to how their work is used. However, it could also be exploited by unscrupulous firms.

If a project is licensed with a permissive license, such as MIT or Apache, firms could take the code and do whatever they want with it once its released. If a project is not finished, they could quickly finish the project and release it as a proprietary product with no release of the added code.

One idea to reduce some of the moral ambiguity of Service Learning programs is to move towards HFOSS. This more explicitly connects Service Learning in the context of engineering to traditional community service work, and helps to make it look less like an unpaid internship. It would help to emphasize the service part of Service Learning.

Another idea is to mandate restrictive licenses such as GPL could serve to ensure student's work isn’t exploited by unscrupulous firms to build proprietary products.

\section{5 - Conclusion}

A consistent theme through this entire paper has been definitional ambiguity. Sometimes the ambiguity has simply been due to a field moving faster than the field can be formalized. At 
other times, it's due to fundamental disagreements held by the practitioners working in the field. And, sometimes, it's just due to sloppiness. But, the definitional ambiguity is not without consequences.

The consequences in some cases are more minor than in others. In the case of service learning, the definitional ambiguity has perhaps assisted in its spread. Institutions have various stakeholders who all hold their own interests and values. The lack of a clear definition for service learning has allowed various institutions to take the concept and adapt it for their own purposes. If one believes Service Learning should just be a useful pedagogical tool with the widest possible adaptation, this is a good thing. However, if one places more emphasis on the revolutionary aspects of service learning, this flexibility can be a massive flaw.

A lot of service learning seems to be missing the emphasis on social and community benefits envisioned by much of the movement's founders. In fact, some of it, especially in fields like engineering, is difficult to distinguish from a traditional internship. The definition of Service Learning is flexible enough that if an institution so desires, the social and community aspects can be almost completely wiped away.

If the revolutionary side of the Service Learning movement wishes to push its values to the forefront, they'll have to build a more precise definition of Service Learning, and then find some mechanism through which to convince others to adapt it. Otherwise, Service Learning will likely remain an additive pedagogical method.

Some other definitional ambiguities are more serious, for example, the ambiguities around the labor status of service learning students, and the status of laborers in general. Given the importance of the distinction between categories such as employees, interns, and volunteers, 
one would hope that there would be clear lines between the categories. However, at least in the United States, the lines are not clear at all.

The dangers of this are numerous, both for employers in general, and the organizations involved in Service Learning in particular. For employers or sponsors, it puts them at risk to have to pay employees they didn't think they needed to pay. This could be especially harmful to charitable or nonprofit organizations. For students, it puts them at risk of doing the work of an employee without the pay of an employee. Until there is more clarity in the regulatory system, all sides will be at some degree of risk. Either legislators or the Supreme Court should take action to provide some form of clarity to the current chaotic situation.

The same speed that lead to the definitional ambiguity problem leads to other problems: such as a lack of ethical reflection. There are numerous documents to be found on the theoretical foundations of Service Learning, and the more practical aspects of running a Service Learning program, but almost no articles reflecting on the ethical challenges involved in it. Of the few that exist, they focus on the obligations of the students towards the organizations and the university. I could find none, other than legal papers, that focused on the obligation of the university and the organizations towards the students. I think this is a major hole that figures of authority in the Service Learning movement need to grapple with.

There are some general suggestions I can make for Service Learning practitioners. First, I'd suggest that sponsors who are individuals incorporate in some way to reduce their risk. Second, I'd suggest that any for-profit corporations involved in Service Learning read the local and national laws and be very careful that the work the students are involved in falls under the category of internship and not employee. If an organization gives students the work of employees, they might be at risk of having to pay them like employees. 
For Portland State Computer Science in particular, I also have a few suggestions. I would recommend a more thorough screening process for sponsors. Specifically, I'd recommend leaning towards projects that are more in the tradition of community service. There is a good precedent for this in HFOSS. It might also be worth mandating restrictive open source licenses such as the GPL in order to help prevent the potential exploitation of the free labor of the students. 


\section{References}

Bessen, J. (2006). 3 - Open Source Software: Free Provision of Complex Public Goods. In J. Bitzer \& P. J. H. Schröder (Eds.), The Economics of Open Source Software Development (pp. 57-81). https://doi.org/10.1016/B978-044452769-1/50003-2

Bodtke, E. (2014). When volunteers become employees: Using a threshold-remuneration test informed by the Fair Labor Standards Act to distinguish employees from volunteers. Minn. L. Rev., 99, 1113.

Bonaccorsi, A., \& Rossi, C. (2006). Comparing motivations of individual programmers and firms to take part in the open source movement: From community to business. Knowledge, Technology \& Policy, 18(4), 40-64.

Budd, P. (2015). All Work and No Pay: Establishing the Standard for When Legal, Unpaid Internships Become Illegal, Unpaid Labor. https://doi.org/10.17161/1808.20285

Christensen, K., Rundus, D., \& Prodanoff, Z. (2003). Partnering with industry for a computer science and engineering capstone senior design course. ASEE Southeast Section Annual Conference. Citeseer.

Conway, J. M., Amel, E. L., \& Gerwien, D. P. (2009). Teaching and Learning in the Social Context: A Meta-Analysis of Service Learning's Effects on Academic, Personal, Social, and Citizenship Outcomes. Teaching of Psychology, 36(4), 233-245. https://doi.org/10.1080/00986280903172969

Cram, S. B. (1998). The Impact of Service-Learning on Moral Development and Self-Esteem of Community College Ethics Students. Retrieved from https://eric.ed.gov/?id=ED460701 Criteria for Accrediting Computing Programs, 2019 - 2020 | ABET. (n.d.). Retrieved April 16, 2019, from https://www.abet.org/accreditation/accreditation-criteria/criteria-foraccrediting-computing-programs-2019-2020/

Egger, J. B. (2008). No service to learning:“Service-learning” reappraised. Academic Questions, 21(2), 183-194. 
Ellis, H. J. C., Hislop, G. W., Jackson, S., \& Postner, L. (2015). Team Project Experiences in Humanitarian Free and Open Source Software (HFOSS). Trans. Comput. Educ., 15(4), 18:1-18:23. https://doi.org/10.1145/2684812

Faust, M., Greenberg, A., \& Pejcinovic, B. (2012). Redesign of senior capstone program in electrical and computer engineering and its assessment. 2012 Frontiers in Education Conference Proceedings, 1-6. https://doi.org/10.1109/FIE.2012.6462390

Flynn, E. (2015). From Capstones to Strategic Partnerships: The Evolution of Portland State University’s Community Engagement and Partnership Agenda. Metropolitan Universities, 26(3), 159-170.

Gacek, C., \& Arief, B. (2004). The many meanings of open source. IEEE Software, 21(1), 34-40.

Godfrey, P. C. (2000). A moral argument for service-learning in management education. Working for the Common Good: Concepts and Models for Service-Learning in Management, 2142.

Kecskes, K., Spring, A., \& Lieberman, D. (2004). 18: The Hesburgh Certificate and Portland State University’s Faculty Development Approach to Supporting Service Learning and Community-University Partnerships. To Improve the Academy, 22(1), 287-301. https://doi.org/10.1002/j.2334-4822.2004.tb00416.x

Kennedy, E. M. (1990, November 16). Text - S.1430 - 101st Congress (1989-1990): National and Community Service Act of 1990 [Webpage]. Retrieved April 13, 2019, from https://www.congress.gov/bill/101st-congress/senate-bill/1430/text

Kenny, M. E., \& Gallagher, L. A. (2002). Service-learning: A history of systems. In Learning to Serve (pp. 15-29). Springer.

Kezar, A., \& Rhoads, R. A. (2001). The dynamic tensions of service learning in higher education: A philosophical perspective. The Journal of Higher Education, 72(2), 148-171.

Kolenko, T. A., Porter, G., Wheatley, W., \& Colby, M. (1996). A critique of service learning projects in management education: Pedagogical foundations, barriers, and guidelines. Journal of Business Ethics, 15(1), 133-142. https://doi.org/10.1007/BF00380269 
Kollock, P. (2019). The Economies of Online Cooperation: Gifts and Public Goods in Cyberspace.

Lemley, M. A. (1995). Convergence in the Law of Software Copyright. Berkeley Technology Law Journal, 10(1), 1.

Maldonado, C. (2018, July 24). Price Of College Increasing Almost 8 Times Faster Than Wages. Retrieved May 13, 2019, from Forbes website: https://www.forbes.com/sites/camilomaldonado/2018/07/24/price-of-college-increasingalmost-8-times-faster-than-wages/

Massey, B. (2019, February 4). IP Law and Open Source. Retrieved April 24, 2019, from http://wiki.cs.pdx.edu/capstone/fall_2018/notes/ip.html

Mooney, L. A., \& Edwards, B. (2001). Experiential learning in sociology: Service learning and other community-based learning initiatives. Teaching Sociology, 181-194.

Munroe, R. (2015, October 30). xkcd: Git. Retrieved May 8, 2019, from https://xkcd.com/1597/

Pearce, J. A. (2018). The Future of Independent Contractors and Their Status as Non-Employees: Moving on from a Common Law Standard. Hastings Bus. LJ, 14, 1.

Phillips, R. (2008). Deadly Combinations: A Framework for Analyzing the GPL's Viral Effect, 25 J. Marshall J. Computer \& Info. L. 487 (2008). The John Marshall Journal of Information Technology \& Privacy Law, 25(3), 2.

Pollack, S. (1999). Early connections between service and education. Service-Learning: A Movement's Pioneers Reflect on Its Origins, Practice, and Future, 12-32.

Prentice, M., \& Garcia, R. M. (2000). Service learning: The next generation in education. Community College Journal of Research \& Practice, 24(1), 19-26.

PSU CS Capstone Sponsor Information [Wiki]. (2017, August 19). Retrieved May 22, 2019, from http://wiki.cs.pdx.edu/capstone/sponsors.html

Ramaley, J. A. (1996). Large-Scale Institutional Change to Implement an Urban University Mission: Portland State University. Journal of Urban Affairs, 18(2), 139-151. 
Raymond, E. (2012, June 11). Why I think RMS is a fanatic, and why that matters. Retrieved April 20, 2019, from Armed and Dangerous website: http://esr.ibiblio.org/?p=4386

Sigmon, R. (1979). Service-learning: Three principles. Synergist, 8(1), 9-11.

Stallman, R. (2009). Viewpoint: Why “Open Source” Misses the Point of Free Software. Commun. ACM, 52(6), 31-33. https://doi.org/10.1145/1516046.1516058

Stanton, T., Giles, D., \& Cruz Nadinne. (1999). Service-Learning: A Movement's Pioneers Reflect on its Origins, Practice, and Future. Jossey-Bass.

Swartz, A. (2006, August 31). Wikimedia at the Crossroads (And Others) [Blog]. Retrieved February 10, 2019, from RAW THOUGHT by Aaron Swartz website: http://www.aaronsw.com/weblog/wikiroads

Westheimer, J., \& Kahne, J. (1994). In the Service of What? The Politics of Service Learning. White, C. R. (1994). A model for comprehensive reform in general education: Portland State University. The Journal of General Education, 168-229. 